\title{
A Comparative Study of the Use of Financial Graphs in the Corporate Annual Reports of Major U.S. and U.K. Companies
}

\author{
Vivien Beattie* \\ University of Stirling \\ Michael John Jones \\ Cardiff Business School
}

\begin{abstract}
The use of graphs to disclose information in corporate annual reports represents a significant dimension in financial disclosure management. Surprisingly, no inter-country comparative analysis of this area of voluntary disclosure has been conducted. This study compares the graphical reporting practices in the 1990 annual reports of 176 leading U.S. and U.K. industrial companies. Ninety-two per cent of U.S. companies use graphs compared with $80 \%$ of U.K. companies; the mean number of graphs per company being 13.0 and 7.7, respectively. Sales, an earnings measure, earnings per share and dividends per share are the four most frequently graphed aggregate financial performance variables in both countries. Significant differences in several of the variables graphed are found and explained in terms of environmental factors. In both countries, evidence of graphical information manipulation exists in the form of selectivity, measurement distortion, and presentational enhancement. Moderate evidence supports the hypothesis that U.K. companies are more likely than U.S. companies to adopt interpretative shading. Regulators need to clarify the responsibilities of directors and auditors by setting graphical guidelines.
\end{abstract}

\section{Introduction}

The extent of voluntary information disclosed in the corporate annual report has increased over the last two decades as managers have exploited the annual report's potential as a major public relations and promotional opportunity (Hanson, 1989; Lee, 1994; Hopwood, 1996). Voluntary information is particularly important as managements are provided with

\footnotetext{
* Correspondence may be addressed to either author: Vivien Beattie, Reader in Accountancy and Finance, Department of Accountancy and Finance, University of Stirling, Stirling FK9 4LA or Michael John Jones, Professor of Financial Reporting, Cardiff Business School, Aberconway Building, Colum Drive, Cardiff CF1 3EU.

We would like to thank Andrew Young for his assistance with data collection. We are grateful to John Richard Edwards, Maurice Pendlebury, Paul Shoemaker, and two anonymous referees for their helpful comments. A previous version of this paper was presented at the 1996 European Accounting Association's Conference, Bergen, Norway.
} 
an opportunity partially to set their own financial reporting agendas. In a cross-cultural context, voluntary disclosure studies permit researchers to make international comparisons of financial reporting practices. Perhaps surprisingly, this aspect of comparative international research has been relatively neglected. This applies, in particular, to bilateral studies of the U.S. and the U.K., countries which are believed to influence strongly financial reporting practices internationally (Mason, 1978; Nobes and Parker, 1995, p. 10). Few studies of the comparative, voluntary disclosure policies of these two countries have been conducted (for example, Barrett, 1976; Guthrie and Parker, 1990; Roberts, 1990; Meek et al., 1995), with the scope of these studies typically being multilateral, rather than bilateral. Substantial similarities are known to exist between U.S. and U.K. mandatory financial reporting practices (see, for example, Nobes, 1995, p. 107). Voluntary information therefore assumes enhanced importance as it highlights differential managerial attitudes.

One important area of voluntary disclosure, the disclosure of financial information using graphs, has not, to our knowledge, been the subject of any systematic comparative study, although several single-country studies have been conducted. This is particularly surprising as approximately $80 \%$ of leading U.S. and U.K. companies use graphs in their corporate annual reports, typically displaying them prominently. Moreover graph use is selective, with graphs often being designed specifically to enhance the user's perception of corporate performance (Steinbart, 1989; Beattie and Jones, 1992a, b).

Financial graphs display financial information in an alternative format to the traditional alphanumeric table combined with continuous narrative text. Essentially, graphs are more user-friendly than tables. Graphs potentially have several advantages over the more traditional format. Graphs, especially when in color, attract the reader's attention; while the reader's ability to remember visual information is normally superior to that for remembering numerical or textual information (Leivian, 1980). In addition, graphs facilitate comparisons and the identification of trends (Korol, 1986). They also synthesize key performance indicators in a readily accessible form.

Recent U.K. survey evidence reveals that more than $75 \%$ of shareholders desire the inclusion of additional graphs in annual reports to help explain financial performance (The Accountant's Magazine, 1992), while in the U.S. Squiers reports that $40 \%$ of stockholders spend five minutes or less looking at an annual report $(1989$, p. 218). In such circumstances, the messages portrayed in colorful, prominently presented graphs are likely to represent oases of interest for the reader. The important role of graphic 
presentation in the external financial reporting process of organizations is also being recognized increasingly by regulatory bodies in a number of countries (Canadian Institute of Chartered Accountants, 1993; Charity Commission, 1993, p. 3).

Companies' managements, however, have incentives to represent their companies' performance in the best possible light, potentially resulting in "selective financial misrepresentation" (Tweedie and Whittington, 1990; Revsine, 1991). The presentational format of accounting information demonstrably affects human perceptions and judgments of performance and is contingent on environmental variables (Thomas, 1991, pp. 45-46). Accounting narratives have been shown to be non-neutral in presentation (Aerts, 1994), photographs have been used for "impression management" (Preston et al., 1996), ${ }^{1}$ while graphical formats, mediated by task characteristics, influence information acquisition and evaluation behaviors (Blocher et al., 1986; Kaplan, 1988; Sullivan, 1988; DeSanctis and Jarvenpaa, 1989; Davis, 1989; Jarvenpaa, 1989). Graphs, being voluntary, provide managements with an enhanced opportunity to manipulate the financial signals sent to users. Birnberg et al. (1983, pp. 120-122) identify biasing (selection of favorable signals) and focusing (enhancement/degradation of aspects of the information set) as two types of information manipulation. Such framing effects, also described as interpretative shading, have been shown to alter significantly the meaning attributed by readers (Tversky and Kahneman, 1981; Bazerman, 1990). In particular, Hofstedt (1972) shows that these framing effects extend to financial reporting. In the context of corporate reporting, the financial disclosure management literature has been extended from the management of reported accounting numbers to encompass the presentation and interpretation of data (Gibbins et al., 1990).

Interpretative shading can occur in financial graphs in several ways. First, managements can, from year to year, selectively choose both whether to use graphs at all and, if used, which specific financial variables to graph. Managements may, for example, be more inclined to present financial performance graphs in "good" years rather than in "bad" years. Second, managements may choose (or permit) graphical construction techniques which distort the message conveyed. For example, rising data trends may be exaggerated by constructing graphs with non-zero axes and/or sharply increasing trend lines). Third, managements may choose (or permit) graph design features which enhance the message conveyed by the accounting numbers in an unwarranted manner. The potential for interpretative shading increases due to the unaudited nature of graphs which are included 
in documents containing the audited financial statements. Regulatory pronouncements in both countries merely state that auditors should review additional sections of the annual report for material inconsistencies with the audited financial statements (AICPA, 1975; APC, 1985). ${ }^{2}$ This responsibility may mitigate the interpretative shading practices described above.

The main purpose of the present study is to investigate the way in which leading companies, in both the U.S. and the U.K., communicate financial information to external users using graphs. This contributes to two distinct literatures. By focusing on the extent of graph use and the specific variables graphed, we contribute to extant knowledge and understanding of comparative voluntary disclosure practices. By documenting evidence of manipulation in graph usage (either in terms of selectivity, graph construction, or design), we advance the scholarly debate into the communicative effectiveness of corporate reporting and, specifically, contribute to the management of financial disclosure literature.

The remainder of the paper consists of four sections, followed by a conclusion. Section two outlines the theoretical and empirical literature on graph perception, construction, and design, and then reviews the findings of existing single-country studies into U.S. and U.K. graphical reporting practices. ${ }^{3}$ We then discuss briefly the similarities and differences between the U.S. and U.K. environments, and present our hypotheses. The methods used in the study are described in section three. Section four, the most substantive section of the paper, presents our results. In section five, we compare our findings with those of major previous single-country studies and provide a discussion.

\section{Prior Literature}

\section{Statistical Graphics}

An understanding of the basic principles of graph construction and design is required if graphs are to exploit fully their communicative potential. Significant progress in applying the theory of visual information processing to the task of graph reading has been made recently by statistical graphics researchers (Cleveland and McGill, 1987; Kosslyn, 1989, 1994). This underpins a specialist theory of graphical perception (i.e., the visual decoding of a graph's quantitative information). In reading a graph, we initially perform rapid visual scans to detect the geometric patterns which form the basis of our inferences about the data's behavior. These initial perceptual tasks may (but, importantly, may not) be followed by more 
highly cognitive tasks such as scale reading. A detailed discussion of the theory of graphical perception, together with the corresponding principles of graph construction and design, is provided in Beattie and Jones (1992a, ch. 2, 1994). Consequently, only a summary is provided below.

The fundamental principle which underpins the construction of graphs is that the physical measures representing the numerical values and the numerical values themselves should be in direct proportion (Tufte, 1983, p. 56). Violations of this principle are termed measurement distortions (Beattie and Jones, 1992b, p. 293). In the case of line and column graphs, this implies that non-zero axes, broken axes, and non-arithmetic scales result in distortion (Schmid and Schmid, 1979; Kosslyn, 1989, p. 208).

In addition, recent theoretical and experimental studies in statistical graphics suggest that the accuracy of judgments depends critically upon the graph's slope parameter (which is the angle of the graph's underlying trend line), with the optimal slope parameter being $45^{\circ}$ (Cleveland and McGill, 1987; Cleveland et al., 1988; Hollands and Spence, 1992; Cleveland, 1993, 1994). Displays which diverge from $45^{\circ}$ are described as exhibiting orientation distortion (Cleveland et al., 1988, p. 293). The slope parameter can be used to "invite the reader to draw inferences and to be sensitive to connotations that are not explicitly present" (Simcox, 1984, p. 483). (See Beattie and Jones [1997] for a review of work in this area.)

It is important to recognize that measurement distortion and orientation distortion are quite separate issues. Measurement distortion arises from incorrect graphic construction, whereas orientation distortion arises when the construction of the graph, though technically accurate, does not facilitate the accuracy of judgments based upon it. Either, neither, or both forms of distortion may thus be present in individual graphs.

The role of other graph construction and design features in the communicative effectiveness of graphs is analyzed in the three levels of Kosslyn's (1989) hierarchical framework: syntactic, semantic, and pragmatic. This framework focuses on the basic components of the graph (background, coordinate axes, specifier, labels, etc.) and specifies their interrelations at the three levels. Effective communication requires that the graph does not violate "acceptability principles" at any level. Conventionally, time series graphs are rectilinear coordinate graphs comprising four structural components: background, framework, specifier, ${ }^{4}$ and labels. To comply with acceptability principles, the background should be unobtrusive; the framework should consist of axes formed by the intersection of two perpendicular lines, with each axis scaled in equal units starting from zero; there should be gridlines; time should run from left to right (with bar graphs, ${ }^{5}$ 
time should run from top to bottom); the width of specifiers and the spaces between them (interspaces) should be uniform and be neither disproportionately long and narrow nor excessively short and wide; three-dimensional specifiers should be avoided, since they can lead to perceptual ambiguity; specifiers should be colored with care since the human perception of color is very complex (in particular, variations in color intensity should not suggest a correspondence with numerical values); labelling should include graph titles, descriptive axis labels, and numeric labels to indicate scale values; and the numeric labels should be located close to the axes, be horizontal, and use a consistent typeface (Kosslyn, 1989). The impact of departures from these normative principles on a reader's understanding has not been examined experimentally. Such departures may, however, impair understanding and, moreover, may be manipulated by graph-makers to enhance favorable, and obscure unfavorable, messages. We term such departures presentational enhancement.

In sum, if the risk of interpretative shading is to be avoided, then financial graphs should adhere to the following major principles of good graphical construction and design:

- the use of financial graphs should not be contingent upon financial performance;

- the physical measures on the surface of the graph should be in direct proportion to the underlying numbers;

- axes' scales should be chosen so that the slope parameter approximates $45^{\circ}$, thereby maximizing judgment accuracy;

- backgrounds should be non-obtrusive;

- all specifiers in time series graphs should be drawn with equal emphasis;

- axes' scales should start at zero and be equally spaced; and

- labelling should be horizontal and consistent.

\section{Single Country Studies of Graphical Reporting Practices}

We know of no previous bilateral U.S.-U.K. comparison of financial information using graphs. There are, however, four single-country empirical studies of graphical formatting choices in corporate annual reports in these two countries (in the U.S., Johnson et al., 1980; Steinbart, 1989, and, in the U.K., Sugden, 1989; Beattie and Jones, 1992a, b). Johnson et al.'s (1980) study was based on a small sample of 50 annual reports for 1977 and 1978, randomly selected from the Fortune 500. One hundred and 
twenty-five graphs from 21 annual reports were found to be "improperly constructed" with reference to a limited set of recommended construction and design criteria. Steinbart's (1989) study was based on 319 annual reports for 1986 selected from the Fortune 500. Two hundred and fiftytwo $(79 \%)$ annual reports contained graphs. Mean measurement distortion across three key financial variables (sales, net income, and dividends) was $+11 \%$. In addition, a significant association was found between favorable discrepancies and decreases in corporate annual net income, suggesting that companies which experience a decline in net income attempt to disguise this by using graphical distortion to portray a more favorable performance than is warranted. Steinbart did not explore potential associations between the incidence of graph use and/or level of measurement distortion and the magnitude of and/or trend in net income (or other performance variables).

In the U.K., Sugden (1989) provides various examples of graphical abuse, but did not undertake a systematic empirical study. Beattie and Jones (1992a, b) investigate the annual reports of 240 large U.K. companies for 1989. They found the mean number of graphs per annual report to be 5.9 , with $65 \%$ of companies graphing at least one key financial variable (sales, earnings, earnings per share [EPS], and dividends per share [DPS]). ${ }^{6}$ Companies with "good" financial performance were found to be significantly more likely to display these variables graphically. Material measurement distortions were detected in $30 \%$ of key financial graphs, with the underlying numerical data being exaggerated by a mean of $+10.7 \%$. Graph construction and design principles were frequently violated, and were biased towards enhancing users' perceptions of company performance.

\section{U.S. and U.K. Environments}

Gernon and Wallace (1996) distinguish five distinct environmental aspects of accounting ecology: societal (structural and cultural), organizational, professional, individual, and accounting. In most respects, the U.S. and the U.K. have similar accounting ecologies. However, we highlight below some differences relating to the structural and accounting elements of each society, in terms of stock ownership and regulatory framework.

The pattern of stock ownership varies between the two countries. In particular, private ownership predominates in the U.S., while institutional ownership is predominant in the U.K. (Frost and Pownall, 1994, p. 89). The power of institutional stockholders vis-à-vis private stockholders in 
the U.K. has been asserted to place additional short-term pressures on company managements, since fund managers themselves are evaluated on the basis of their short-term performance. Empirical research by Arnold et al. (1984) confirms this, with U.S. analysts analyzing, on average, 5.7 years data compared to 4.6 for the U.K. In addition, U.S. analysts forecast, on average, 30 months ahead, compared to only 23 months in the U.K. Demirag (1995) also finds some evidence that U.K. group finance directors perceive themselves as subject to short-term pressures. ${ }^{7}$

The regulatory framework within the U.S. for listed companies is more stringent than that in the U.K. As at November 1996, in the U.S. there are 97 detailed accounting standards, in addition to 21 APB opinions, in force, while in the U.K., there are only 25 (17 Statements of Standard Accounting Practice and eight Financial Reporting Standards) extant standards of a more general nature. In the U.S., the Securities and Exchange Commission (SEC) mandates that a very detailed $10-\mathrm{K}$ report be filed annually by companies. There is no U.K. equivalent to the SEC, although successive Companies Acts have laid down general, but increasingly stringent, statutory accounting provisions. On balance, though, “(d)espite the lack of Companies Acts, financial reporting for SEC-registered companies is subject to more detailed regulation in the United States" (Nobes, 1995, p. 169).

In addition, there are several major differences in accounting practice. U.S. companies frequently use the last-in, first-out (LIFO) method of inventory valuation, account for deferred tax under the full provision method, and write-off goodwill over 40 years (rather than immediately to reserves). Moreover, U.K. companies frequently revalue fixed assets, a practice not common in the U.S. In sum, these accounting differences result in U.S. reported earnings being lower than U.K. reported earnings. To illustrate, when 39 U.K. companies' earnings (1991/92) were restated using U.S. Generally Accepted Accounting Principles (GAAP), reported earnings were lower in 36 cases and the mean decrease in earnings was 41.2\% (from Ernst and Young [1992], reproduced in Nobes [1995, p. 168]; calculations by the present authors). On the whole, U.S. GAAP are, therefore, more conservative than U.K. GAAP (Weetman and Gray, 1990). On the user side, Frost and Pownall (1994) argue that the demand for accounting information will be higher in the U.S., due to the higher concentration of private investors. Overall, therefore, not only are U.S. listed companies more stringently regulated, but U.S. GAAP also leads them to report generally lower profits than would be the case under U.K. GAAP. 


\section{Hypotheses}

To provide a framework for our study, we have developed four general hypotheses (stated in alternative form), drawing on the above literatures.

First, private investors are, in general, less sophisticated than corporate or institutional stockholders. In addition, graphs have the potential to enhance the effective communication of financial information. We, therefore, hypothesize that:

H1: U.S. companies will use graphs more extensively than U.K. companies in their annual report.

Second, corporate and institutional stockholders generally have a shorter investment horizon than private investors, hence:

H2: U.S. companies will adopt a longer-term view than U.K. companies when reporting financial information.

Third, in both countries managerial incentives exist for impression management, hence:

H3: Interpretative shading of graphs, using the devices of selectivity, measurement distortion, orientation distortion, and presentational enhancement, will occur in both countries.

Fourth, we speculate that, compared to the U.K., the increased regulatory stringency and more conservative GAAP may "spill over" to graphical reporting practices, leading U.S. companies to undertake less interpretative shading than U.K. companies. This difference may be exacerbated by the more litigious U.S. financial reporting environment. ${ }^{8}$ Hence:

H4: Interpretative shading of graphs, using the devices of selectivity, measurement distortion, orientation distortion, and presentational enhancement, will be greater in the U.K. than in the U.S.

\section{Methods}

The largest (based on sales) 100 U.S. and 100 U.K. industrial companies were selected from the Times 1000 directory for 1990-1991 (Times Books, 1990). The largest companies were chosen due to their economic significance. This selection strategy was designed to match the samples in terms of their domestic economic significance and precluded explicit matching by size. Financial companies were excluded, due to inherent differences 
in the structure of their financial statements. A written request was made to each company for their 1990 annual report. Given that 1990 marks the start of a world recession, poor corporate performance can be expected to increase the incentives to present financial results in the most favorable light. After extensive follow-up, a usable sample of 85 U.S. and 91 U.K. annual reports was achieved. ${ }^{9}$ For each company, information about the use, construction, and design of graphs, and financial performance was collected using a revised version of Beattie and Jones' (1992a, b) data collection sheet. In particular, measurement distortion was calculated, using a graph discrepancy index based on Tufte's (1983) lie factor, as follows:

$$
\text { graph discrepancy index }=[(\mathrm{a} / \mathrm{b})-1] * 100 \%,
$$

where $\mathrm{a}=$ percentage change $($ in $\mathrm{cm}$ ) depicted in graph, and

$\mathrm{b}=$ percentage change in data.

This index is zero in the absence of measurement distortion, positive if the graph exaggerates the data trend, and negative if the graph understates the trend. Slope parameters were measured using a protractor. All data were coded and entered into a database for subsequent analysis.

\section{Results}

\section{Descriptive}

Graphs, although widely used in both countries, were more commonly found in the U.S.: 78 (92\%) U.S. companies used graphs in their annual reports compared to $73(80 \%)$ U.K. companies. ${ }^{10}$ This difference is statistically significant at the $5 \%$ level $\left(\chi^{2}=3.9\right)$ and $\mathrm{H} 1$ is supported. Sales, an absolute earnings measure, EPS, and DPS were the most frequently graphed aggregate time series financial performance variables in both countries. The specific earnings measure graphed, however, was net earnings in the U.S. and earnings (i.e., profit before tax) in the U.K. Arnold et al. (1984) suggest that the relative preference for before tax earnings in the U.K. may be accounted for by the more judgmental system of deferred taxation in the U.K. than in the U.S. We term these four variables key financial variables (KFVs), following Beattie and Jones (1992a, b). ${ }^{11}$ Table 1 details the incidence of KFVs graphed. No statistically significant difference is present in the proportion of companies in each country which graph an absolute earnings measure, EPS, or DPS. However, $66 \%$ of U.S. 
Table 1. Incidence of Graph Use in the Corporate Annual Reports of Large Listed Companies

\begin{tabular}{|c|c|c|c|c|}
\hline \multirow[b]{3}{*}{ Variable graphed } & \multicolumn{4}{|c|}{ Companies } \\
\hline & \multicolumn{2}{|c|}{ U.S. $(n=85)$} & \multicolumn{2}{|c|}{ U.K. $(n=91)$} \\
\hline & No. & $\%$ & No. & $\%$ \\
\hline Any variable & 78 & 92 & 73 & 80 \\
\hline \multicolumn{5}{|l|}{ Key financial variables: } \\
\hline sales & 56 & 66 & 34 & 37 \\
\hline earnings & 42 & 49 & 41 & 45 \\
\hline earnings per share (EPS) & 48 & 56 & 46 & 51 \\
\hline dividends per share (DPS) & 36 & 42 & 45 & 49 \\
\hline $\begin{array}{l}\text { Mean no. of graphs per } \\
\text { annual report }\end{array}$ & \multicolumn{2}{|c|}{13.0} & \multicolumn{2}{|c|}{7.7} \\
\hline
\end{tabular}

companies graph sales, compared with only $37 \%$ of U.K. companies (statistically significant at the $1 \%$ level $\left[\chi^{2}=13.2\right]$ ). Thus, although many companies in each country do not graph sales at all, U.S. managements choose to graph sales more frequently than their U.K. counterparts. This may reflect a relatively greater focus by U.S. companies, compared to U.K. companies, on long-term growth (as reflected by sales), rather than on short-term profitability (as reflected by earnings measures).

An analysis of all topics graphed 10 or more times by either country is given in Table 2, which is arranged in order of descending topic frequency for U.S. companies. Companies overwhelmingly graph financial variables (such as sales) rather than non-financial variables (such as employees or employment data). Table 2 also shows the corresponding percentage of total graphs and the percentage of graph-using companies which graph each topic. The mean number of graphs found in the annual reports of U.S. companies is 13.0, compared to 7.7 in the U.K., providing further support for $\mathrm{H} 1$. These means rise to 14.2 and 9.7, respectively, if only graph-using companies are included (statistically significant at the $1 \%$ level, based on a two-tailed t-test of the difference between means $[\mathrm{t}=3.36, \mathrm{p}=0.001]$ ).

With respect to individual topics, segmental graphs and KFV graphs account for a large proportion of all graphs in both countries: $27 \%$ and $16 \%$ for the U.S.; $34 \%$ and $22 \%$ for the U.K. ${ }^{12}$ In absolute terms, U.S. companies graph more segmental information than U.K. companies. This reinforces previous research studies which show that U.S. companies disclose more segmental information (mandatory and voluntary) than other 
Table 2. Analysis of Topics Graphed

\begin{tabular}{|c|c|c|c|c|c|c|c|}
\hline \multirow[b]{2}{*}{ Topic ${ }^{l}$} & \multicolumn{3}{|c|}{ U.S. (78 graph-using companies) } & \multicolumn{3}{|c|}{ U.K. (73 graph-using companies) } & \multirow[b]{2}{*}{$\begin{array}{c}\chi^{2} \text { test } \\
\text { statistic }^{2}\end{array}$} \\
\hline & $\begin{array}{c}\text { Total } \\
\text { number } \\
\text { of graphs }\end{array}$ & $\begin{array}{c}\% \text { of total } \\
\text { graphs }\end{array}$ & $\begin{array}{c}\% \text { of } \\
\text { graph-using } \\
\text { companies } \\
\text { graphing topic }\end{array}$ & $\begin{array}{c}\text { Total } \\
\text { number } \\
\text { of graphs }\end{array}$ & $\begin{array}{l}\text { \% of total } \\
\text { graphs }\end{array}$ & $\begin{array}{c}\% \text { of } \\
\text { graph-using } \\
\text { companies } \\
\text { graphing topic }\end{array}$ & \\
\hline Key financial variable graphs ${ }^{3}$ & 177 & 16.0 & 91.0 & 157 & 22.3 & 80.8 & 2.48 \\
\hline $\begin{array}{l}\text { Segmental (time series analysis of sales } \\
\text { by business sector) }\end{array}$ & 105 & 9.5 & 44.9 & 52 & 7.4 & 23.3 & $6.85^{* * *}$ \\
\hline $\begin{array}{l}\text { Segmental (time series analysis of key earnings } \\
\text { measure by business sector) }\end{array}$ & 78 & 7.0 & 33.3 & 53 & 7.5 & 20.5 & 2.50 \\
\hline Capital expenditure & 53 & 4.8 & 55.1 & 19 & 2.7 & 15.1 & $24.63 * * *$ \\
\hline $\begin{array}{l}\text { Segmental (non-time series analysis of sales } \\
\text { by business sector) }\end{array}$ & 51 & 4.6 & 28.2 & 34 & 4.8 & 26.0 & 0.01 \\
\hline Return on equity & 35 & 3.2 & 44.9 & 6 & 0.8 & 8.2 & $23.79 * * *$ \\
\hline Measure of market size/market share & 32 & 2.9 & 3.8 & 16 & 2.3 & 15.1 & 4.39 \\
\hline Financial gearing & 26 & 2.3 & 32.1 & 6 & 0.9 & 8.2 & $11.71 * * *$ \\
\hline $\begin{array}{l}\text { Segmental (non-time series analysis of key } \\
\text { earnings measure by business sector) }\end{array}$ & 26 & 2.3 & 10.3 & 24 & 3.4 & 21.9 & 3.01 \\
\hline $\begin{array}{l}\text { Segmental (time series analysis of sales by } \\
\text { geographical location) }\end{array}$ & 24 & 2.2 & 16.7 & 6 & 0.8 & 2.7 & $6.69 * * *$ \\
\hline Share price & 23 & 2.1 & 25.6 & 7 & 1.0 & 9.6 & $5.57 * * *$ \\
\hline Return on sales (i.e., margin) & 16 & 1.4 & 15.4 & 16 & 2.3 & 11.0 & 0.32 \\
\hline $\begin{array}{l}\text { Earnings measures (other than profit before tax } \\
\text { for U.K., and net earnings for U.S.) }\end{array}$ & 15 & 1.4 & 16.7 & 28 & 4.0 & 28.8 & 2.51 \\
\hline Net asset value per share & 13 & 1.2 & 16.7 & 1 & 0.1 & 1.4 & $8.75 * * *$ \\
\hline
\end{tabular}


Table 2. Continued

\begin{tabular}{|c|c|c|c|c|c|c|c|}
\hline \multirow[b]{2}{*}{ Topic $^{l}$} & \multicolumn{3}{|c|}{ U.S. (78 graph-using companies) } & \multicolumn{3}{|c|}{ U.K. (73 graph-using companies) } & \multirow[b]{2}{*}{$\begin{array}{c}\chi^{2} \text { test } \\
\text { statistic }^{2}\end{array}$} \\
\hline & $\begin{array}{c}\text { Total } \\
\text { number } \\
\text { of graphs }\end{array}$ & $\begin{array}{l}\text { \% of total } \\
\text { graphs }\end{array}$ & $\begin{array}{l}\% \text { of } \\
\text { graph-using } \\
\text { companies } \\
\text { graphing topic }\end{array}$ & $\begin{array}{c}\text { Total } \\
\text { number } \\
\text { of graphs }\end{array}$ & $\begin{array}{l}\text { \% of total } \\
\text { graphs }\end{array}$ & $\begin{array}{c}\% \text { of } \\
\text { graph-using } \\
\text { companies } \\
\text { graphing topic }\end{array}$ & \\
\hline $\begin{array}{l}\text { Dividends (measures other than key } \\
\text { dividend variable) }\end{array}$ & 13 & 1.2 & 16.7 & 1 & 0.1 & 1.4 & $8.75^{* * *}$ \\
\hline Assets (variable) & 11 & 1.0 & 12.8 & 3 & 0.4 & 4.1 & 2.61 \\
\hline Market indices—stocks/shares & 10 & 0.9 & 5.1 & 3 & 0.4 & 4.1 & 0.01 \\
\hline $\begin{array}{l}\text { Segmental (non-time series analysis of sales by } \\
\text { geographical location) }\end{array}$ & 10 & 0.9 & 7.7 & 23 & 3.3 & 19.2 & 3.39 \\
\hline $\begin{array}{l}\text { Segmental (non-time series analysis of key } \\
\text { earnings measure by geographical location) }\end{array}$ & 1 & 0.1 & 1.3 & 19 & 2.7 & 15.1 & $8.00 * * *$ \\
\hline Other & 387 & 35.0 & & 231 & 32.8 & & \\
\hline Total & 1106 & 100.0 & & 705 & 100.0 & & \\
\hline
\end{tabular}

1. Segmental graphs not specifically listed in the table are 3 (U.S.) and 8 (U.K.) time series analysis of key earnings measures by geographical location and 18 (U.K.) "secondary" segmental graphs, e.g., time series graphs of a more detailed sub-division of an individual segment.

2. *** = significant at the $1 \%$ level (two-tailed).

3. In 5 (U.S.) and 9 (U.K.) cases, two key financial variables were shown on one graph (c.f. Table 1). 
Table 3. Distribution of All Graphs by Type

\begin{tabular}{lrrrrr}
\hline & \multicolumn{2}{c}{ U.S. } & \multicolumn{2}{c}{$U . K$} \\
\cline { 2 - 3 } \cline { 5 - 6 } Graph type & No. & $\%$ & & No. & \multicolumn{1}{c}{$\%$} \\
\hline Bar/column & 874 & 79.0 & 440 & 62.4 \\
Line & 65 & 5.9 & 89 & 12.6 \\
Pie & 152 & 13.7 & 152 & 21.6 \\
Other & 15 & 1.4 & 24 & 3.4 \\
Total & 1106 & 100.0 & 705 & 100.0 \\
\hline
\end{tabular}

countries worldwide (Gray et al., 1984; Gray and Radebaugh, 1984). This can be attributed partly to the larger number of segments identified by U.S. companies, since separate graphs are often included for each segment. In both countries, time series segmentation is more popular than non-time series segmentation, and graphs segmented by business sector rather than geographical location are more frequent. A possible reason for the latter finding is that competitive disadvantage is perceived by company managements to be associated more with geographical, rather than business segment, disclosures (Edwards and Smith, 1996). In the U.S., time-series graphs of sales by business sector are the most popular, whereas in the U.K. time series graphs of sales and earnings by business sector occur approximately equally. This reinforces our earlier findings with respect to the relative popularity of aggregate sales graphs in the U.S. The only other topics representing more than $3 \%$ of the total number of graphs in each country were capital expenditure (4.8\%) and return on equity $(3.2 \%)$ in the U.S. and, in the U.K., earnings measures other than profit before tax (the U.K. earnings KFV) (4.0\%).

The final column reports the results of chi-square tests of independence between topic graphed and country. Nine topics show an association between graph use and country at the $1 \%$ level of significance. In eight of these cases, the incidence of graph use is higher for U.S. companies. U.S. companies are statistically more likely to graph time series of sales by both business sector and geographical location, which reinforces our earlier finding with respect to the relative popularity of aggregate sales graphs, whereas U.K. companies are statistically more likely to graph non-time series of earnings by geographical location. U.S. companies are also statistically more likely to graph capital expenditure, return on equity, financial gearing, share price, net asset value per share, and dividends. 
An analysis of all graphs by generic type is shown in Table 3. Although bar/column graphs are the most common graph type in both countries, they are relatively more popular in the U.S. than in the U.K. This is attributable largely to the fact that U.S. companies graph relatively more time series segmental graphs and relatively less non-time series segmental graphs compared to U.K. companies; time series graphs are best presented as bar/column graphs, while non-time series graphs are more appropriately presented as pie graphs. From now on we focus on KFV graphs.

\section{Selectivity}

We investigated whether graphs were more likely to be included in the annual reports of companies with "favorable" rather than "unfavorable" financial performance in three ways. First, we tested whether the inclusion of at least one of the four KFV graphs (sales, earnings, EPS, or DPS) was associated with favorable performance in EPS, the performance indicator most widely used by the financial markets (Arnold et al., 1984). Increases in EPS were classed as favorable performance, while decreases in EPS were classed as unfavorable. Performance was measured over both one and five years. ${ }^{13}$ We investigated whether the inclusion (i.e., presence or absence) of at least one KFV graph was associated with the directional change in EPS (i.e., increase or decrease) using a chi-square test of independence. The results are shown in Table 4, panel A (i.e., rows 1 and 2), col. 1 (U.S.) and col. 6 (U.K.). Take, as an example, the relationship between the presence or absence of at least one of the four KFV graphs (sales, earnings, EPS, or DPS) in the U.S. and the increase or decrease in EPS over the current year (panel A, row 1, col. 1). In this particular example, the chisquare statistic is 3.70 , which is significant at the $5 \%$ level. In other words, U.S. companies were significantly more likely to include at least one KFV graph when EPS increased over the current year than when EPS had decreased. In fact, of the 50 U.S. companies whose EPS increased over the current year, $45(90 \%)$ included at least one KFV graph, whereas only 26 (74\%) of the 35 companies whose EPS decreased did so.

Second, we tested whether the presence or absence of a particular KFV graph (sales, earnings, EPS, or DPS) was contingent upon increases or decreases in EPS (panel A, rows 1 and 2; cols 2-5 for the U.S. and cols 7-10 for the U.K.). For example, in row 2, col. 9, we test whether the presence or absence of an EPS graph in the U.K. is dependent upon the direction of change in EPS over five years. We find a chi-square statistic of 9.36, which is significant at the $1 \%$ level. Thus, U.K. companies are 
Table 4. Tests of the Relationship Between the Presence or Absence of Graphs for Four Key Financial Variables (KFVs) and the Increase or Decrease in Performance Indicators. Chi-square test statistic $\left(\chi^{2}\right)$ (one-tailed probability below)

\begin{tabular}{|c|c|c|c|c|c|c|c|c|c|c|}
\hline \multirow[b]{2}{*}{$\begin{array}{l}\text { Performance } \\
\text { indicator }^{l}\end{array}$} & \multicolumn{5}{|c|}{ Presence of U.S. Graphs } & \multicolumn{5}{|c|}{ Presence of U.K. Graphs } \\
\hline & $\begin{array}{l}\text { Col. } 1 \\
\text { At least one of } \\
\text { the four KFV } \\
\text { graphs }\end{array}$ & Col. 2 & $\begin{array}{l}\text { Col. } 3 \\
\text { Net } \\
\text { earnings }\end{array}$ & Col. 4 & Col. 5 & $\begin{array}{c}\text { Col. } 6 \\
\text { At least one of } \\
\text { the four KFV } \\
\text { graphs }\end{array}$ & Sales & Earnings & $\begin{array}{l}\text { Col. } 9 \\
\text { EPS }\end{array}$ & Col. 10 \\
\hline \multicolumn{11}{|c|}{ Panel A-Directional change in EPS measured as: } \\
\hline $\begin{array}{l}\text { Row } 1 \\
\text { increase or decrease } \\
\text { in current year } \\
\text { (U.S.: } \mathrm{n}=85 \text {; } \\
\text { UK: } \mathrm{n}=77 \text { ) }\end{array}$ & $\begin{array}{l}3.70 \\
0.028 * *\end{array}$ & $\begin{array}{l}0.24 \\
0.311\end{array}$ & $\begin{array}{l}2.11 \\
0.073 *\end{array}$ & $\begin{array}{l}0.62 \\
0.216\end{array}$ & $\begin{array}{l}0.66 \\
0.208\end{array}$ & $\begin{array}{l}5.17 \\
0.011^{* *}\end{array}$ & $\begin{array}{l}0.95 \\
0.164\end{array}$ & $\begin{array}{l}3.06 \\
0.040 * *\end{array}$ & $\begin{array}{l}10.40 \\
0.000 * * *\end{array}$ & $\begin{array}{l}6.42 \\
0.005^{* * *}\end{array}$ \\
\hline $\begin{array}{l}\text { Row } 2 \\
\text { upward or downward } \\
\text { trend over five years } \\
\text { (U.S.: } \mathrm{n}=80 \text {; } \\
\text { U.K.: } \mathrm{n}=71 \text { ) }\end{array}$ & $\begin{array}{l}9.51 \\
0.001 * * *\end{array}$ & $\begin{array}{l}1.15 \\
0.141\end{array}$ & $\begin{array}{l}1.51 \\
0.109\end{array}$ & $\begin{array}{l}4.22 \\
0.020 * *\end{array}$ & $\begin{array}{l}5.57 \\
0.009 * * *\end{array}$ & $\begin{array}{l}13.26 \\
0.000 * * *\end{array}$ & $\begin{array}{l}2.08 \\
0.074 *\end{array}$ & $\begin{array}{l}4.38 \\
0.018 * *\end{array}$ & $\begin{array}{l}9.36 \\
0.001 * * *\end{array}$ & $\begin{array}{l}8.57 \\
0.001 * * *\end{array}$ \\
\hline
\end{tabular}




\begin{tabular}{|c|c|c|c|c|c|c|c|c|c|c|}
\hline \multirow[b]{2}{*}{$\begin{array}{l}\text { Performance } \\
\text { indicator }^{1}\end{array}$} & \multicolumn{5}{|c|}{ Presence of U.S. Graphs } & \multicolumn{5}{|c|}{ Presence of U.K. Graphs } \\
\hline & $\begin{array}{l}\text { Col. } 1 \\
\text { At least one of } \\
\text { the four KFV } \\
\text { graphs }\end{array}$ & Col. 2 & $\begin{array}{c}\text { Col. } 3 \\
\text { Net } \\
\text { earnings }\end{array}$ & $\begin{array}{l}\text { Col. } 4 \\
\text { EPS }\end{array}$ & Col. 5 & $\begin{array}{l}\text { Col. } 6 \\
\text { At least one of } \\
\text { the four KFV } \\
\text { graphs }\end{array}$ & Col. 7 & $\begin{array}{c}\text { Col. } 8 \\
\text { Earnings }\end{array}$ & $\begin{array}{l}\text { Col. } 9 \\
\text { EPS }\end{array}$ & Col. 10 \\
\hline \multicolumn{11}{|c|}{ Panel B-Directional change in matched KFV measured as: } \\
\hline $\begin{array}{l}\text { Row } 3 \\
\text { increase or decrease } \\
\text { in current year } \\
\text { (U.S.: } \mathrm{n}=85 \\
\text { U.K.: } \mathrm{n}=91 \\
\text { unless specified) }\end{array}$ & $\begin{array}{l}\text { Not } \\
\text { applicable }\end{array}$ & $\begin{array}{l}0.63 \\
0.213\end{array}$ & $\begin{array}{l}2.83 \\
0.046^{* *}\end{array}$ & $\begin{array}{l}\text { As for } \\
\text { panel A }\end{array}$ & $\begin{array}{l}\text { note } 2 \\
0.318\end{array}$ & $\begin{array}{l}\text { Not } \\
\text { applicable }\end{array}$ & $\begin{array}{l}2.66 \\
0.051^{*}\end{array}$ & $\begin{array}{l}2.92 \\
0.040 * *\end{array}$ & $\begin{array}{l}\text { As for } \\
\text { panel A }\end{array}$ & $\begin{array}{l}\text { note } 2 \\
\mathrm{n}=77 \\
0.010 * * *\end{array}$ \\
\hline $\begin{array}{l}\text { Row } 4 \\
\text { upward or downward } \\
\text { trend over five years } \\
\text { (U.S.: } \mathrm{n}=79 ; \\
\text { unless specified; } \\
\text { U.K.: } \mathrm{n}=\text { as specified) }\end{array}$ & $\begin{array}{l}\text { Not note } \\
\text { applicable }\end{array}$ & & $\begin{array}{l}1.67 \\
0.098^{*}\end{array}$ & $\begin{array}{l}\text { As for } \\
\text { panel A }\end{array}$ & $\begin{array}{l}\text { note } 2 \\
0.090^{*}\end{array}$ & $\begin{array}{l}\text { Not } \\
\text { applicable }\end{array}$ & $\begin{array}{l}\text { note } 2 \\
\mathrm{n}=77 \\
0.338\end{array}$ & $\begin{array}{l}5.80 \\
\mathrm{n}=82 \\
0.008 * * *\end{array}$ & $\begin{array}{l}\text { As for } \\
\text { panel A }\end{array}$ & $\begin{array}{l}\text { note } 2 \\
\mathrm{n}=66 \\
0.050 * *\end{array}$ \\
\hline
\end{tabular}

1. Sample sizes vary according to data availability.

2. Where the chi-square test was invalid due to $\geqslant 33 \%$ of cells having expected frequencies of $<5$, the Fisher exact probability test was used.

3. There were no instances of a downward trend to permit comparative testing.

4. Observation of the cell frequencies in each contingency table showed that the direction of all results was as expected for all tests (except for the incidence of U.S. sales graphs related to the change in sales over the current year).

$*=$ significant at the 0.1 level; $* *=$ significant at the 0.05 level; $* * *=$ significant at the 0.01 level. 
significantly more likely to include an EPS graph when EPS has increased rather than decreased.

Third, we tested whether the inclusion of particular KFV graphs (sales, earnings, EPS, or DPS) was associated with favorable performance, again measured over the current year and five years. Performance in this case was defined as the direction of change in the particular variable graphed (for example, sales variable matched against sales trend). Increases in the trend measures were classed as favorable, while decreases were classed as unfavorable. Results from the series of chi-square tests are shown in Table 4, panel B (i.e., rows 3 and 4), cols 2-5 for the U.S. and cols 7-10 for the U.K. For example, for the U.S., the relationship between the presence or absence of a net earnings graph and the increase or decrease in net earnings in the current year is tested in row 3, col. 3. The chi-square statistic is 2.83 , which is significant at the $5 \%$ level. In other words, U.S. companies are significantly more likely to include graphs of net earnings when net earnings have increased rather than decreased.

Panel A shows that in both countries a significant association exists between the use of at least one KFV graph and EPS performance, especially over five years (significant at the $1 \%$ level; col. 1 for the U.S. and col. 6 for the U.K.). Across the four individual KFVs, the five year trend (row 2), rather than the current year change (row 1), in EPS performance is more strongly associated with graph use in six out of eight cases. The results obtained for the U.K. are typically more robust than those for the U.S. In the U.S., a strong association (significant at the $1 \%$ level) exists between the existence of a DPS graph and the five year trend in EPS (row 2, col. 5). In the U.K., strong associations (significant at the $1 \%$ level) exist between the existence of EPS as well as DPS graphs and both the current year change (row 1, cols 9 and 10) and the five year trend in EPS (row 2, cols 9 and 10). Significant associations over both one year (four out of five cases) and five years (all five cases) therefore exist in the U.K., whereas in the U.S. few significant associations exist when performance is assessed over one year (two out of five cases). A short-term view thus appears more common in the U.K. This is consistent with $\mathrm{H} 2$.

Panel B shows that results are less consistent and significant based on the performance of the particular financial variable. There are, however, two significant associations at the $1 \%$ level in the U.K.: between the existence of DPS graphs and the current year change in DPS (row 3, col. 10) and between the existence of earnings graphs and the five year trend in EPS (row 4, col. 8). In combination, the findings from both panels 
Table 5. Length of Time Series Graphed-Key Financial Variables

\begin{tabular}{|c|c|c|c|c|}
\hline \multirow[b]{2}{*}{ Years } & \multicolumn{2}{|c|}{ U.S. } & \multicolumn{2}{|c|}{$U . K}$. \\
\hline & No. & $\%$ & No. & $\%$ \\
\hline$<5$ & 17 & 9 & 24 & 15 \\
\hline 5 & 128 & 70 & 113 & 68 \\
\hline $6-9$ & 12 & 7 & 12 & 7 \\
\hline 10 & 17 & 9 & 15 & 9 \\
\hline$>10$ & 8 & 5 & 2 & 1 \\
\hline Total & 182 & 100 & 166 & 100 \\
\hline Mean no. of years graphed & \multicolumn{2}{|c|}{5.9} & \multicolumn{2}{|c|}{5.6} \\
\hline
\end{tabular}

A and B indicate that KFV graphs are used selectively in both countries, supporting H3. In addition, we found the U.K. to exhibit greater selectivity, supporting $\mathrm{H} 4$.

Table 5 shows five years to be the most common length of time series graphed, representing $70 \%$ of U.S. and $68 \%$ of U.K. KFV graphs. We investigated whether the selection of a time series shorter than this norm was associated with the desire to avoid showing any decrease in performance in consecutive years. In $27 \%$ and $29 \%$ of the cases where a shorter period was chosen by U.S. and U.K. companies, respectively, the years graphed showed a continuous upward trend, whereas a five year graph would have failed to do so. This suggests that, in an important minority of cases, the length of time series selected is associated with trend performance. The mean number of years graphed in KFV graphs was 5.9 in the U.S. and 5.6 in the U.K. (not statistically significant at the $1 \%$ level, based on a two-tailed t-test of the difference between means $[\mathrm{t}=0.83, \mathrm{p}=0.409]$ ). This finding is also suggestive of a more short-term view being adopted by U.K. companies, consistent with $\mathrm{H} 2$.

\section{Measurement Distortion}

The incidence of measurement distortion is shown in Table 6. A 5\% materiality threshold was selected, following Pany and Wheeler (1989) and Beattie and Jones (1992b, p. 298). ${ }^{14}$ Twenty-four per cent of graphs were materially distorted in both the U.S. (43 out of 182) and the U.K. (40 out of 166), consistent with H3. The vast majority of distortions exaggerated the underlying trend, especially in the U.S. The mean level of measurement distortion was greater in the U.S. (+15.6\%) than in the U.K. 
Table 6. Incidence of Materially Discrepant Graphs

\begin{tabular}{|c|c|c|c|c|c|c|c|c|c|c|}
\hline \multirow[b]{2}{*}{ Graph discrepancy index (GDI) } & \multicolumn{5}{|c|}{ U.S.-Key financial variables } & \multicolumn{5}{|c|}{ U.K.-Key financial variables } \\
\hline & Sales & Net earnings & $E P S$ & $D P S$ & Total & Sales & Earnings & EPS & $D P S$ & Total \\
\hline $\begin{array}{l}\text { Material exaggeration of trend, } \\
\text { i.e., GDI } \geqslant 5 \%\end{array}$ & 10 & 10 & 7 & 7 & 34 & 5 & 8 & 11 & 5 & 29 \\
\hline $\begin{array}{l}\text { Material understatement of trend } \\
\text { i.e., GDI } \leqslant-5 \%\end{array}$ & 1 & 5 & 2 & 1 & 9 & 2 & 3 & 3 & 3 & 11 \\
\hline No material discrepancy & 45 & 27 & 39 & 28 & 139 & 27 & 30 & 32 & 37 & 126 \\
\hline Total & 56 & 42 & 48 & 36 & 182 & 34 & 41 & 46 & 45 & 166 \\
\hline Mean discrepancy index (\%) & +10.3 & +14.9 & +6.7 & +36.4 & +15.6 & +15.2 & +5.7 & +5.5 & +3.2 & +6.9 \\
\hline
\end{tabular}


$(+6.9 \%)$, which fails to support H4. This difference between means is, however, not statistically significant at the $1 \%$ level, based on a two-tailed $\mathrm{t}$-test $(\mathrm{t}=1.26, \mathrm{p}=0.207) .{ }^{15} \mathrm{~A}$ particularly striking result, which is attributable partly to one extremely large observation caused by a non-zero axis, is the high mean level of distortion in U.S. DPS graphs $(+36.4 \%)$. Excluding this observation, the DPS mean falls to $+10.6 \% .{ }^{16}$ The underlying reason for material discrepancies was seldom attributable to a specific cause such as a non-zero axis or non-arithmetic scale, rather the graphic distance portrayed simply was not proportionate to the underlying numerical values.

\section{Orientation Distortion}

The slope parameter measures the angle (orientation) of the graph's trend line. If the data remains constant over time, this angle will be $0^{\circ}$. If, however, the data increase, say, doubles over the period, the graph could be constructed so that the angle of the trend line varied considerably, depending on the scales selected. For example, "long and narrow" graphs would have trend lines markedly above $45^{\circ}$ while "short and wide" graphs would have trend lines markedly below $45^{\circ}$. As discussed in section II, the suggested optimum for continually rising trends is $+45^{\circ}$ (Cleveland and McGill, 1987; Hollands and Spence, 1992). Table 7 shows that only 19\% of U.S. and U.K. key financial graphs with continuous upward trends lie within $5^{\circ}$ of this figure. Consequently, $81 \%$ depart more than $5^{\circ}$ from the optimum. Twenty-four per cent of both U.S. and U.K. graphs have a slope parameter which is more than $25^{\circ}$ below the optimum, i.e., below $20^{\circ}$. By contrast, no graphs have a slope parameter above $70^{\circ}$, which is more than $25^{\circ}$ above the optimum. The mean deviation from the $45^{\circ}$ optimum is $16.4^{\circ}$ in both countries. The overall mean slope parameter is less than the optimum in both countries: $33.5^{\circ}$ in the U.S. and $34.5^{\circ}$ in the U.K. ${ }^{17}$ No systematic orientation distortion is, therefore, present in either country, i.e., no evidence is found of companies deliberately using slope parameters in excess of $45^{\circ}$ to enhance users' perceptions of financial performance. Overall, remarkable unanimity exists in the key characteristics of the slope parameter in both countries. Neither H3 nor H4 is supported in respect of orientation distortion.

\section{Presentational Enhancement}

In this sub-section, we report the extent to which the construction and design of KFV graphs depart from normative acceptability principles. The 
Table 7. Slope Parameter of Key Financial Graphs With Continuous Upward Trend $\left(\right.$ Optimal $\left.=45^{\circ}\right)$

\begin{tabular}{|c|c|c|c|c|c|c|c|c|c|c|c|c|}
\hline \multirow{3}{*}{$\begin{array}{l}\text { Angle } \\
x^{0}\end{array}$} & \multicolumn{6}{|c|}{ U.S.-Key financial variables } & \multicolumn{6}{|c|}{ U.K.-Key financial variables } \\
\hline & \multirow{2}{*}{$\begin{array}{l}\text { Sales } \\
\text { No. }\end{array}$} & \multirow{2}{*}{$\begin{array}{c}\text { Net } \\
\text { earnings } \\
\text { No. }\end{array}$} & \multirow{2}{*}{$\begin{array}{l}E P S \\
N o .\end{array}$} & \multirow{2}{*}{$\begin{array}{l}D P S \\
N o .\end{array}$} & \multicolumn{2}{|c|}{ Total } & \multirow{2}{*}{$\begin{array}{l}\text { Sales } \\
\text { No. }\end{array}$} & \multirow{2}{*}{$\begin{array}{c}\text { Earnings } \\
\quad \text { No. }\end{array}$} & \multirow{2}{*}{$\begin{array}{l}\text { EPS } \\
\text { No. }\end{array}$} & \multirow{2}{*}{$\begin{array}{c}D P S \\
N o .\end{array}$} & \multicolumn{2}{|c|}{ Total } \\
\hline & & & & & No. & $\%$ & & & & & No. & $\%$ \\
\hline $0 \leqslant x<10$ & - & 3 & 2 & 3 & 8 & 8 & 1 & 1 & - & 2 & 4 & 3 \\
\hline $10 \leqslant x<20$ & 6 & 2 & - & 9 & 17 & 16 & 6 & 3 & 4 & 12 & 25 & 21 \\
\hline $20 \leqslant x<30$ & 9 & 1 & 1 & 10 & 21 & 21 & 4 & 7 & 9 & 7 & 27 & 23 \\
\hline $30 \leqslant x<40$ & 8 & 2 & 5 & 4 & 19 & 19 & 4 & 3 & 7 & 9 & 23 & 19 \\
\hline $40 \leqslant x<50$ & 9 & 4 & 2 & 5 & 20 & 20 & 6 & 5 & 6 & 6 & 23 & 19 \\
\hline $50 \leqslant x<60$ & 2 & 2 & 6 & - & 10 & 10 & 2 & 2 & 1 & 2 & 7 & 6 \\
\hline $60 \leqslant x<70$ & 3 & 1 & 1 & 1 & 6 & 6 & 2 & 2 & 3 & 4 & 11 & 9 \\
\hline Total & 37 & 15 & 17 & 32 & 101 & 100 & 25 & 23 & 30 & 42 & 120 & 100 \\
\hline Mean & $35.1^{\circ}$ & $32.9^{\circ}$ & $43.2^{\circ}$ & $26.8^{\circ}$ & $33.5^{\circ}$ & - & $34.0^{\circ}$ & $36.4^{\circ}$ & $36.1^{\circ}$ & $31.9^{\circ}$ & $34.5^{\circ}$ & - \\
\hline
\end{tabular}


Table 8. Type of Graph Used for Key Financial Variables

\begin{tabular}{|c|c|c|c|c|}
\hline \multirow[b]{2}{*}{ Graph type } & \multicolumn{2}{|c|}{$U . S}$. & \multicolumn{2}{|c|}{$U . K}$. \\
\hline & $\begin{array}{c}\text { No. of } \\
\text { Companies }\end{array}$ & $\%$ & $\begin{array}{c}\text { No. of } \\
\text { Companies }\end{array}$ & $\%$ \\
\hline Column & 47 & 66 & 39 & 66 \\
\hline Tower (i.e., 3D column) & 9 & 13 & 9 & 16 \\
\hline Bar & 4 & 5 & 1 & 2 \\
\hline Line & 3 & 4 & 3 & 5 \\
\hline Symbol used as column/bar & 2 & 3 & 2 & 3 \\
\hline Other & 2 & 3 & 3 & 5 \\
\hline Mixed & 4 & 6 & 2 & 3 \\
\hline Total & 71 & 100 & 59 & 100 \\
\hline
\end{tabular}

statistical graphics literature has not yet advanced to the stage where the effect of such departures has been tested empirically. Table 8 analyzes the type of graph used to display the KFVs. A column graph is the most suitable type, since the KFV graphs relate exclusively to time series data (Schmid, 1983). In both countries, two-thirds of graphs use simple twodimensional columns, with three-dimensional column graphs next in popularity. In the U.S. and U.K., four companies and one company, respectively, use bar graphs (unsuitable for the display of time series data) and three companies in both countries use a line graph (overly suggestive of a causal link between the two variables).

The KFV graphs are all based on the rectilinear coordinate system (with the exception of one pie graph series). Our findings on violations of construction and design principles (see section II) are detailed in Table 9 (chisquare values of significant inter-country differences are also provided). Below we focus principally only on those instances where the U.S. and the U.K. adopt markedly different presentational approaches. In all these cases, the U.K. appears to adopt a more short-term perspective.

In the U.S., two companies showed specifiers progressively darkening in color with time, one showed the last year only in a darker color and two showed the last year only in a different color. The corresponding figures for the U.K. were much higher: four, six, and seven cases, respectively. The latter two differences are statistically significant at the $10 \%$ level. Thus, U.K. companies are more inclined to use color to highlight the latest year's performance, a finding which, arguably, reinforces the short-term perspective adopted in the U.K. and is supportive of $\mathrm{H} 2$ and H4. In terms 
Table 9. Summary of Non-Compliance With Normative Graph Construction and Design Principles

\begin{tabular}{|c|c|c|c|c|c|}
\hline \multirow[b]{2}{*}{ Structural components } & \multicolumn{2}{|c|}{$\begin{array}{c}\text { U.S. } \\
\text { (71 companies) }\end{array}$} & \multicolumn{2}{|c|}{$\begin{array}{c}U . K . \\
(58 \text { companies })^{I}\end{array}$} & \multirow[b]{2}{*}{$\chi^{2}$} \\
\hline & No. & $\%$ & No. & $\%$ & \\
\hline \multicolumn{6}{|l|}{ Framework } \\
\hline No scaled time axis & 33 & 46.5 & 35 & 60.3 & 1.94 \\
\hline No scaled financial variable axis & 35 & 49.3 & 36 & 62.1 & 1.62 \\
\hline $\begin{array}{l}\text { Financial variable axis located, } \\
\text { unconventionally, at right hand side }\end{array}$ & 14 & 19.7 & 7 & 12.1 & 0.87 \\
\hline No gridlines & 46 & 64.8 & 46 & 79.3 & 2.62 \\
\hline Unconventional ordering of time series & 6 & 8.5 & 1 & 1.7 & 1.66 \\
\hline Non-horizontal baseline & 3 & 4.2 & - & - & 1.00 \\
\hline \multicolumn{6}{|l|}{ Specifiers } \\
\hline Three-dimensional specifier & 12 & 16.9 & 14 & 24.1 & 0.64 \\
\hline Specifier color progressively darkened & 2 & 2.8 & 4 & 6.9 & 0.45 \\
\hline $\begin{array}{l}\text { Specifier color in last year darker than } \\
\text { uniform color of prior years }\end{array}$ & 1 & 1.4 & 6 & 10.3 & $3.38 *$ \\
\hline $\begin{array}{l}\text { Specifier color of last year different hue } \\
\text { than prior years }\end{array}$ & 2 & 2.8 & 7 & 12.1 & $2.91 *$ \\
\hline \multicolumn{6}{|l|}{ Labels } \\
\hline Incomplete numeric labels on time axis & 3 & 4.2 & 2 & 3.4 & 0.05 \\
\hline $\begin{array}{l}\text { No numeric labels on financial variable } \\
\text { axis }\end{array}$ & 35 & 49.3 & 35 & 60.3 & 1.16 \\
\hline $\begin{array}{l}\text { No number attached to individual } \\
\text { specifier }\end{array}$ & 31 & 43.7 & 20 & 34.5 & 0.77 \\
\hline $\begin{array}{l}\text { Unconventional location of numeric } \\
\text { labels on time axis }\end{array}$ & 5 & 7.0 & 6 & 10.3 & 0.12 \\
\hline $\begin{array}{l}\text { Unconventional location of number } \\
\text { attached to individual specifiers }\end{array}$ & 14 & 19.7 & 8 & 13.8 & 0.43 \\
\hline $\begin{array}{l}\text { Incomplete series of numbers attached } \\
\text { to individual specifiers }\end{array}$ & 4 & 5.6 & 2 & 3.4 & 0.03 \\
\hline $\begin{array}{l}\text { Numeric labels on time axis not } \\
\text { horizontal }\end{array}$ & 3 & 4.2 & 1 & 1.7 & 0.09 \\
\hline $\begin{array}{l}\text { Number attached to specifier not } \\
\text { horizontal }\end{array}$ & 4 & 5.6 & 5 & 8.6 & 0.10 \\
\hline $\begin{array}{l}\text { Typeface changes within series of } \\
\text { numeric labels on time axis designed } \\
\text { to emphasize final year }\end{array}$ & 1 & 1.4 & 10 & 17.2 & $8.33 * * *$ \\
\hline $\begin{array}{l}\text { Typeface changes within series of } \\
\text { numbers attached to specifier designed } \\
\text { to emphasize final year }\end{array}$ & 1 & 1.4 & 7 & 12.1 & $4.54 * *$ \\
\hline
\end{tabular}

1. Excludes the one pie graph series.

$*=$ Significant at the 0.1 level; $* *=$ significant at the 0.05 level; $* * *=$ significant at the 0.01 level. 
of typeface consistency, U.K. companies were once again more likely than their U.S. counterparts to emphasize the final year of a time series trend (using devices with statistically significant differences at $1 \%$ and $5 \%$ levels). ${ }^{18}$ This supports $\mathrm{H} 2$ and $\mathrm{H} 4$.

\section{Comparison with Single Country Studies and Discussion}

\section{Comparisons with Single Country Studies}

In this sub-section, we compare our findings with those obtained by the major previous single-country studies of U.S. and U.K. graphs (Steinbart [1989] in the U.S. and Beattie and Jones [1992 a, b] in the U.K.). Table 10 provides a summary of this comparison. Neither of these previous studies considers either orientation distortion or presentational enhancement. In interpreting Table 10, the potential effects of the different sampling frames and the economic recession which began in 1989 should be considered. One would expect companies with greater political visibility (proxied by corporate size) to be more likely to use graphs (Watts and Zimmermann, 1986). In addition, one would expect the general decline in corporate performance measures by 1990 to have increased managerial incentives to enhance the presentation of corporate performance through impression management, and hence to result in a reduction in the use of time series graphs, greater selectivity in the use of KFV graphs, and a higher level of measurement distortion.

When compared with Steinbart's (1989) study of 1986 U.S. annual reports, the present study indicates that the use of graphs, including KFV graphs, has become more widespread and pervasive in the U.S. by 1990. In particular, the percentage of companies using graphs has risen from $79 \%$ to $92 \%$, with the mean number of graphs per annual report rising from 8.0 to 13.0. These trends are clearly desirable if the graphs are used and constructed in an unbiased way, given their potential to enhance the communicative effectiveness of financial information. Unfortunately, in 1990, evidence of selectivity in the use of KFV graphs still exists (albeit less strong), and the level of measurement distortion has increased from $+11 \%$ to $+15.6 \%$.

The findings of the present study with regard to the U.K. broadly confirm those of Beattie and Jones (1992a, b). The present study, however, finds marginally greater use of graphs, less evidence of selectivity, and a decline in measurement distortion. Thus the impact of the recession on graphical practices is not as expected. The present study focuses on 85 of 
Table 10. Comparison with Major Previous Single Country Studies

\begin{tabular}{|c|c|c|c|c|}
\hline & \multicolumn{2}{|c|}{ U.S. } & \multicolumn{2}{|c|}{$U . K}$. \\
\hline & Steinbart (1989) & This study & $\begin{array}{l}\text { Beattie and Jones } \\
\quad(1992 a, b)\end{array}$ & This study \\
\hline Sample type and size & $\begin{array}{l}1986 \text { annual reports of } \\
319 \text { Fortune } 500 \\
\text { companies }\end{array}$ & $\begin{array}{l}1990 \text { annual reports of } \\
85 \text { leading (by sales) } \\
100 \text { companies }\end{array}$ & $\begin{array}{l}1989 \text { annual reports of } \\
240 \text { top } 500 \text { (by market } \\
\text { capitalization) listed } \\
\text { companies }\end{array}$ & $\begin{array}{l}1990 \text { annual reports of } \\
91 \text { leading (by sales) } \\
100 \text { companies }\end{array}$ \\
\hline $\begin{array}{l}\text { Percentage of companies } \\
\text { using graphs }\end{array}$ & $79 \%$ & $92 \%$ & $79 \%$ & $80 \%$ \\
\hline $\begin{array}{l}\text { Mean number of graphs per } \\
\text { annual report }\end{array}$ & $8.0^{1}$ & 13.0 & 5.9 & 7.7 \\
\hline Key financial variables (KFVs) & $\begin{array}{l}\text { Sales, net income } \\
\text { and dividends }\end{array}$ & $\begin{array}{l}\text { Sales, net income } \\
\text { EPS and DPS }\end{array}$ & $\begin{array}{l}\text { Sales, profit before tax, } \\
\text { EPS and DPS }\end{array}$ & $\begin{array}{l}\text { Sales, profit before tax } \\
\text { (earnings), EPS and DPS }\end{array}$ \\
\hline Number of KFV graphs & 698 & 177 & 465 & 157 \\
\hline $\begin{array}{l}\text { Percentage of companies } \\
\text { displaying at least one } \\
\text { KFV graph }\end{array}$ & $66 \%$ & $84 \%$ & $65 \%$ & $65 \%$ \\
\hline $\begin{array}{l}\text { Association between existence } \\
\text { of at least one KFV graph and } \\
\text { increase/decrease in key } \\
\text { performance measure }\end{array}$ & $\begin{array}{l}\chi^{2}=15.03 \\
(p<0.001)\end{array}$ & $\begin{array}{l}\chi^{2}=3.70 \\
(p=0.028)\end{array}$ & $\begin{array}{l}\chi^{2}=18.80 \\
(p=0.000)\end{array}$ & $\begin{array}{l}\chi^{2}=5.17 \\
(p=0.011)\end{array}$ \\
\hline $\begin{array}{l}\text { Mean measurement distortion } \\
\text { across KFV graphs }\end{array}$ & $+11 \%$ & $+15.6 \%$ & $+10.7 \%$ & $+6.9 \%$ \\
\hline
\end{tabular}

1. Derived from figures reported in Steinbart (1989, p. 63) 
the 100 leading U.S. companies and 91 of the 100 leading U.K. companies, rather than samples from the leading 500, and thus comprises larger companies. This may explain the greater use of graphs.

Overall, therefore, the use of graphs has risen in both countries, possibly attributable to the larger companies within the sampling frame. Our comparison of the findings of the studies by Steinbart (1989) and Beattie and Jones (1992a, b) revealed practices in the U.S. and the U.K. to be remarkably similar. This study, however, shows that graph usage in the U.S. has increased more rapidly in the U.S. than in the U.K. This is true both for the percentage of companies using graphs and the mean number of graphs per annual report. Selectivity in both countries, and measurement distortion in the U.K., have not risen, as might be expected, due to the recession. There has, however, been a marked rise in measurement distortion in the U.S.

\section{Discussion}

The results support hypothesis 1 that U.S. companies will use graphs more extensively than U.K. companies in their annual reports (both in terms of numbers of companies and number of graphs). We offer four, not necessarily mutually exclusive, explanations for this principal finding: the greater level of investor demand for information in the U.S., arising from the higher level of private versus institutional stock ownership (Frost and Pownall, 1994); the more competitive nature of the U.S. capital markets which may lead companies to "increase price efficiency by voluntarily disclosing information about the company" (Gray et al., 1990, p. 599); the greater individualism and freedom in U.S. society (Hofstede, 1980), which may lead U.S. companies to be more open and transparent, releasing more information publicly; and the fact that the U.S. is at least 10 years ahead of the U.K. in transforming the annual report "into a corporate communications tool" (McKinstry, 1996, p. 89). A possible offsetting influence, which clearly does not dominate in the present context, is the more litigious U.S. environment which may lead "to a hesitancy to disclose information on a voluntary basis" (Gray et al., 1990, p. 599).

One of the principal findings to emerge from this study is that managements in the two countries choose to graph different variables. Significantly more U.S. companies graph sales, segmental time series analyses of sales (by both business sector and geographical location), capital expenditure, return on equity, financial gearing, share price, net asset value per share, and dividends, while significantly more U.K. companies graph 
segmental non-time series analyses of earnings (by geographical location). The significantly greater incidence of topics graphed in the U.S. is attributable partly to the relatively greater incidence of graphs in the U.S. per se. In addition, however, we speculate that some of the significant differences may arise from different environmental factors (particularly regulatory requirements) and differential managerial attitudes. For example, the greater prevalence of capital expenditure graphs may be because regulatory requirements in the U.S. require business segmentation of capital expenditure (not required in the U.K.), with the voluntary graphical reporting of this variable being a "spillover effect". It may also be that the greater prevalence of capital expenditure graphs reflects the greater focus by U.S. companies, compared to U.K. companies, on long-term growth and/or their greater sensitivity to capital expenditure levels, caused by criticism that (compared to Japanese companies) they do not invest sufficient funds. (U.S. companies may, in fact, invest more than their U.K. counterparts. ${ }^{19}$ ) Similarly, information on year-end share price and share price trend is mandatory for U.S. companies, whereas this information is voluntary in the U.K. Finally, comparative analysis has shown that the U.S. uses return on investment (analogous to return on equity) more extensively than the U.K. for internal performance measurement and evaluation purpose (Emmanuel et al.,1991). This practice may carry over to external reporting.

The common perception that the U.K. capital market encourages shorttermism was also supported. Graphs of U.K. companies were more likely to be included in corporate annual reports when the performance over one year was favorable, U.K. companies graphed shorter time series, and, finally, devices such as color and typeface were more likely to be used by U.K. companies to emphasize the final year's performance. Therefore, greater U.K. short-termism was reflected in our findings with respect to selectivity, length of time series graphed, and certain presentational enhancements which emphasize the latest year's performance. Hypothesis 2 was supported.

We found general support for hypothesis 3 that companies in both countries would use interpretative shading to enhance users' perceptions of performance. Companies were more likely to include graphs when performance increased rather than decreased, both in terms of EPS and the particular variable graphed. Companies were also more likely to exaggerate rather than understate time trends, giving a generally more favorable view of performance than was warranted by the data. Orientation distortion was widespread, however we found no evidence to indicate that companies systematically used slope parameters in excess of the $45^{\circ}$ optimum 
to enhance users' perceptions of time trends. Finally, we found that companies frequently used a range of presentational devices to enhance information portrayal. Our finding that graphs are more likely to be included in the annual reports of companies with relatively "good" performance (H3) is also supported. The significance of this firm-specific factor suggests that future research into financial graphical reporting practices should explore other firm-specific factors, such as size and industry group, in addition to environmental factors. A priori, larger companies might be expected to use graphs more extensively due to their higher political visibility; the potential influence of industry groups is, however, unclear.

Our findings partially support hypothesis 4 , concerning the relative use of interpretative shading in each country. We hypothesized a higher incidence of selectivity, measurement distortion, orientation distortion, and presentational enhancement in the U.K., due to less conservatism in reporting practices together with comparatively less stringent regulation. Selectivity and presentational enhancement supported this view, however our findings for measurement distortion and orientation distortion were not supportive.

In combination, these results confirm and extend knowledge and understanding of the influence of environmental factors on corporate voluntary accounting practices. They also provide evidence that financial graphs are subject to a degree of "management" by the preparers of annual reports and, consequently, that the potential of this presentational format to enhance communication is impaired.

\section{Summary and Conclusions}

Graphs enhance the potential to communicate, rather then merely to report, financial information and represent an aspect of corporate financial reporting which previously has not been explored in a cross-national context. Moreover, graphs provide opportunities for managements to manipulate the financial signals sent to users. This study conducts a direct comparison of the graphical reporting practices in the 1990 annual reports of 85 leading U.S., and 91 leading U.K., companies. Ninety-two per cent of U.S. companies used graphs compared with $80 \%$ of U.K. companies, the mean number of graphs per company being 13.0 and 7.7, respectively (both statistically significant differences at the $1 \%$ level). The four most frequently graphed aggregate financial performance variables (sales, an absolute earnings measure, EPS, and DPS) were the same in both countries, although significantly more U.S. companies graphed sales. The 
specific earnings measure graphed was earnings after tax in the U.S. and profit before tax in the U.K. Companies in the U.S. generally emphasized sales performance relatively more than U.K. companies, at both the aggregate and segmental level. By contrast, relatively more emphasis was placed upon earnings measures in the U.K. This may reflect relatively greater U.S. interest in long-term growth, rather than short-term earnings, compared to the U.K.

Selectivity in the use of KFV graphs based on company performance is found in both countries; the evidence is, however, stronger with respect to the U.K. In both countries, the presence of at least one KFV graph and EPS performance (especially measured over five years) were strongly associated. Statistical associations measured over only one year are generally stronger in the U.K. relative to the U.S. (suggesting greater U.K. short-termism). Twenty-four per cent of KFV graphs in both the U.S. and the U.K. exhibit material measurement distortion. The mean level of distortion is, however, greater in the U.S. at $16 \%$ compared with $7 \%$ in the U.K. Thus, U.S. graphs exaggerate the underlying numerical values to a greater extent. This contrasts with previous single-country studies which have found similar levels (approximately 11\%) in both countries. Eightyone per cent of KFV graphs in both countries are constructed with a slope parameter which deviated more than $5^{\circ}$ from the $45^{\circ}$ optimum (the mean deviation was $16.4^{\circ}$ for both countries). This impairs the accuracy with which the financial information encoded in the graph will be decoded by the reader. Analysis of aspects of graph design show that U.K. companies have a significantly greater tendency to highlight the latest year's performance (reflecting the U.K.'s greater short-termism) using, in particular, color and typeface variations. In addition, many graphs were found to contain unconventional and potentially inadequate design features. These graphical shortcomings may impair the communicative effectiveness of the financial graphs, although this has not been tested empirically.

Overall, therefore, this study reveals important differences in the way in which financial graphs are used in the U.S. and in the U.K. First, U.S. managers, possibly because of capital market pressures or greater openness, present more voluntary information in graphical format. Second, managements in the U.S. focus on sales more than their U.K. counterparts. Third, greater evidence of short-termism exists in the U.K., both in relation to selectivity, length of time series graphed, and presentational enhancement. Fourth, U.S. managements have a different set of variables which they believe important to communicate to stockholders (particularly, 
capital expenditure and return on equity). Fifth, U.S. managements are more likely to materially distort graphs. While some of these differences (such as short-termism) confirm existing knowledge, others (such as the highlighting by U.S. managements of sales, capital expenditure, and return on equity) are new. This study of financial graphs has thus revealed potentially important, unresearched differences between managerial preferences for voluntary information in the U.S. and the U.K. Further research is needed to explore these cross-cultural differences.

These findings indicate that graphs, although widely used, do not always fulfill their potential to communicate financial information more effectively to external users and frequently display bias. This is due to selectivity in the choice of performance variables graphed, distortions and deviations from optima in the construction of graphs, and departures from normative design principles. These problems are particularly severe in the U.K. Regulators in both countries need to consider seriously a set of accounting and auditing guidelines which will specify the appropriate graphical principles to be used in external financial reporting.

\section{Notes}

1. Impression management represents the use of visual and textual strategies in corporate annual reports to present and highlight only the "facts" or "message" which the company wishes to portray (Preston et al., 1996, p. 119).

2. APC (1985) has now been replaced by APB (1995), however the requirements have not been altered significantly.

3. We do not discuss formally the extensive literature on single-country voluntary disclosures (see, for example, Ball and Foster [1982], Gibbins et al. [1990, 1992], Gray et al. [1995]) as we believe this literature to be of only tangential relevance to the present study. The three bilateral U.S.-U.K. studies of which we are aware are not especially pertinent: Arnold et al. (1984) investigate the investment appraisal methods of financial analysts, Gray et al. (1990) investigate perceptions of cost constraints on voluntary information, while Frost and Pownall (1994) study the frequency and timing of accounting disclosures and assess compliance with disclosure rules. We are not aware of any study focusing, in detail, on bilateral voluntary disclosures. Finally, Meek et al. (1995) examine factors influencing three types of voluntary disclosures (strategic, non-financial, and financial) in the annual reports of MNCs from the U.S., the U.K., and Continental Europe. A significant country effect is found.

4. The specifier is the symbol used to represent specific numerical values, most frequently a column in this study.

5. Although the term "bar graph" is frequently applied to both bar and column graphs, a useful distinction can be made (Schmid, 1983, p. 38). Column graphs, where the specifiers are arranged vertically, are suitable for time series, whereas bar graphs, where the specifiers are arranged horizontally, are suitable for the display of categorical data.

6. Terminology relating to key performance variables differs between the U.S. and the U.K. In the U.K., "turnover" refers to "sales", "profit before tax" refers to "earnings" (or 
"income"), and "profit after tax" refers to "net earnings" (or "net income"). To establish consistency, U.S. terminology is used throughout this paper.

7. Demirag (1995) notes, however, that much of the evidence in his review is merely anecdotal.

8. A possible countervailing influence is that tight mandatory disclosures may lead to more licence being taken in respect of voluntary disclosures.

9. Twelve U.S. companies failed to send annual reports, while three sent reports for the wrong year; six U.K. companies failed to send annual reports, in addition, one had run out of copies, one had ceased to trade, and one had been taken over.

10. Four U.S. and 16 U.K. companies sent two documents (in the U.S., typically the form $10 \mathrm{~K}$ and, in the U.K., usually the annual report and accounts split into two sections): the second document (often the annual review) was analyzed only where the document containing the audited financial statements did not contain graphs. No $10 \mathrm{Ks}$ or supplemental documents of financial and operating statistics were analyzed.

11. This definition of key financial variable thus excludes non-time series graphs (for example, one year segmental pie graphs) and variables which do not directly measure financial revenue performance.

12. Segmental graphs are those which show either the time series performance of an individual business or geographic segment or the division of a single year's aggregate performance into business or geographic segments.

13. For 50 out of $85(59 \%)$ U.S. companies, EPS increased over the current year, compared to increases for 42 out of 77 (55\%) U.K. companies; for 64 out of 80 (80\%) U.S. companies, EPS increased over five years, compared to increases for 58 out of $71(82 \%)$ U.K. companies.

14. Arguably measurement distortion is, in some cases, inevitable due to small values in the first year relative to later years or small differential values between the first and last years graphed. We judged 10 material distortions in the U.S. sample and seven in the U.K. sample to fall into this category. Excluding these cases, the revised overall mean measurement distortion was almost unchanged at $+15.7 \%$ for the U.S. and $+6.9 \%$ for the U.K.

15. The standard deviations of U.S. and U.K. measurement distortions were 81.9 and 35.1 , respectively.

16. The overall mean falls to $+10.5 \%$ if this observation is excluded, which is still significantly higher than the overall U.K. mean measurement discrepancy. There is, however, no prima facie reason to exclude this value.

17. The mean slope parameter of the DPS graphs falls below that of the other variables in both countries. This can be partly explained by the fact that several companies (five U.S. and nine U.K.) include both EPS and DPS on the same graph, using the same scale, and DPS normally falls below EPS. The shape parameter of the key financial graphs (i.e., the height of the data rectangle divided by its width), which is determined by the slope parameter, also varied greatly, ranging from 0.2 (Archer Daniels: sales) to 17.8 (May: net earnings) in the U.S. and from 0.15 (Racal: sales and earnings) to 5.0 (Cable and Wireless: DPS) in the U.K. The overall means were 1.89 and 1.52, for the U.S. and the U.K. respectively.

18. One U.S. company emphasized the final year's numerical label in bold type compared to nine U.K. companies, with a further U.K. company using larger type for this label. One U.S. company emphasized the number attached to the final year's specifier in bold type compared to six U.K. companies, while a further U.K. company used black rather than white as in the previous years.

19. Although not a directly comparable measure, corporate research and development spending in the U.K. is described as "low" by Porter (1990, p. 721). 


\section{References}

Aerts, W., "On the Use of Accounting Logic as an Explanatory Category in Narrative Accounting Disclosures," Accounting, Organizations and Society (1994) 19(4/5), pp. 337-353.

AICPA, "Other Information in Documents Containing Audited Financial Statements," AICPA Professional Standards, Vol. 1, U.S. Auditing Standards, Section 550 (American Institute of Certified Public Accountants, 1975).

APB, "Other Information In Documents Containing Audited Financial Statements," Statement of Auditing Standard 160 (Auditing Practices Board, 1995).

APC, "Financial Information Issued With Audited Financial Statements," Auditing Guideline (Auditing Practices Committee, 1985).

Arnold, J., P. Moizer and E. Noreen, "Investment Appraisal Methods of Financial Analysts: A Comparative Study of U.S. and U.K. Practices," International Journal of Accounting (Spring 1984), pp. 1-18.

Ball, R. and G. Foster, "Corporate Financial Reporting: A Methodological Review of Empirical Research," Journal of Accounting Research, Supplement (1982) 20, pp. 161-234.

Barrett, M. E., "Financial Reporting Practices: Disclosure and Comprehensiveness in an International Setting," Journal of Accounting Research (Spring 1976), pp. 10-26.

Bazerman, M. H., Judgment in Managerial Decision Making (New York: Wiley, 1990).

Beattie, V. A. and M. J. Jones, The Communication of Information Using Graphs in Corporate Annual Reports, Certified Research Report 31, Chartered Association of Certified Accountants (London: Certified Accountants Educational Trust, 1992a).

Beattie, V. A. and M. J. Jones, "The Use and Abuse of Graphs in Annual Reports: A Theoretical Framework and Empirical Study," Accounting and Business Research (Autumn 1992b), pp. 291-303.

Beattie, V. A. and M. J. Jones, "Visual Perception of Financial Information in Corporate Reports: The Role of Graphs," Discussion Paper No. 97/01, University of Stirling, 1997.

Birnberg, J. G., L. Turopolec and S. M. Young, "The Organizational Context of Accounting," Accounting, Organizations and Society (1983) 8(2/3), pp. 111-129.

Blocher, E., R. P. Moffie and R. W. Zmud, "Report Format and Task Complexity: Interactions in Risk Judgements," Accounting, Organizations and Society (1986) 11(6), pp. 457-470.

Canadian Institute of Chartered Accountants, Using Ratios and Graphics in Financial Reporting (Toronto: CICA, 1993).

Charity Commission (U.K.), Accounting by Charities, Statement of Recommended Practice No. 2, Exposure Draft (March 1993).

Cleveland, W. S., Visualizing Data (Summit, NJ: Hobart Press, 1993).

Cleveland, W. S., The Elements of Graphing Data, revised edition (Murray Hill, NJ: A T \& T Laboratories, 1994).

Cleveland, W. S. and R. McGill, "Graphical Perception: The Visual Decoding of Quantitative Information on Graphical Displays of Data," Journal of the Royal Statistical Society A (1987) 150(3), pp. 192-229.

Cleveland, W. S., M. E. McGill and R. McGill, "The Shape Parameter of a Two-Variable Graph," Journal of the American Statistical Association (1988) 83, pp. 289-300.

Davis, L. R., "Report Format and the Decision-Maker's Task: An Experimental Investigation," Accounting, Organizations and Society (1989) 14(5/6), pp. 495-508.

Demirag, I., "Assessing Short-term Perceptions of Group Finance Directors of UK Companies," British Accounting Review (1995) 27, pp. 247-281. 
DeSanctis, G. and S. L. Jarvenpaa, "Graphical Investigation of Accounting Data for Financial Forecasting: An Experimental Investigation," Accounting, Organizations and Society (1989) 14(5/6), pp. 509-525.

Edwards, P. and R. A. Smith, "Competitive Disadvantage and Voluntary Disclosures," British Accounting Review (1996) 28, pp. 155-172.

Emmanuel, C., D. Otley and K. Merchant, Accounting for Management Control (London: Chapman Hall, 1991).

Ernst and Young, US/UK GAAP Comparison (1992).

Frost, C. A. and G. Pownall, "Accounting Disclosure Practices in the United States and the United Kingdom," Journal of Accounting Research (Spring 1994), pp. 75-102.

Gernon, H. and R. S. O. Wallace, "International Accounting Research: A Review of its Ecology, Contending Theories and Methodologies," Journal of Accounting Literature (1995) 14, pp. 54-106.

Gibbins, M., A. Richardson and J. Waterhouse, "The Management of Corporate Financial Disclosure: Opportunism, Ritualism, Policies and Processes," Journal of Accounting Research (Spring 1990) 28, pp. 121-143.

Gibbins, M., A. Richardson and J. Waterhouse, The Management of Financial Disclosure: Theory and Perspectives, Research Monograph Number 20 (Vancouver: The Canadian Certified General Accountant's Research Foundation, 1992).

Gray, R. H., R. Kouhy and S. Lavers, "Corporate Social and Environmental Reporting: A Review of the Literature and a Longitudinal Study of UK Disclosure," Accounting, Auditing and Accountability Journal (1995) 8(2), pp. 47-77.

Gray, S. J. and L. H. Radebaugh, "International Segment Disclosures by U.S. and U.K. Multinational Enterprises: A Descriptive Study," Journal of Accounting Research (Spring 1984), pp. 351-360.

Gray, S. J., L. G. Campbell and J. C. Shaw, International Financial Reporting-A Comparative International Survey of Accounting Requirements and Practices in 30 Countries (London: Macmillan, 1984).

Gray, S. J., L. H. Radebaugh and C. B. Roberts, "International Perceptions of Cost Constraints on Voluntary Information Disclosures: A Comparative Study of U.K. and U.S. Multinationals," Journal of International Business Studies (Fourth Quarter 1990), pp. 597-622.

Guthrie, J. and L. D. Parker, "Corporate Disclosure Practices: A Comparative International Analysis," Advances in Public Interest Accounting (1990) 3, pp. 343-352.

Hanson, J. D., "Developments in Financial Reporting Over the Last 20 Years," in Financial Reporting 1988-89: A Survey of U.K. Published Accounts, L. C. L. Skerratt and D. J. Tonkin, eds. (London: Institute of Chartered Accountants in England and Wales, 1989), pp. 3-13.

Hofstede, G. H., Culture's Consequences: International Differences in Work-Related Values (Beverly Hills, CA: Sage Publications, 1980).

Hofstedt, T. R., "The Behavioral Parameters of Financial Analysis," The Accounting Review (October 1972), pp. 679-692.

Hollands, J. G. and I. Spence, "Judgments of Change and Proportion in Graphical Perception," Human Factors (1992) 34(3), pp. 313-334.

Hopwood, A. G., Editorial, Accounting, Organizations and Society (1996) 21(1), pp. 55-56.

Jarvenpaa, S. L., "The Effect of Task Demands and Graphical Format on Information Processing Strategies," Management Science (March 1989) 35(3), pp. 285-303.

Johnson, J. R., R. R. Rice and R. A. Roemmick, "Pictures That Lie: The Abuse of Graphs in Annual Reports," Management Accounting (October 1980), pp. 50-56.

Kaplan, S. E., "An Examination of the Effect of Presentation Format on Auditors' Expected Value Judgments," Accounting Horizons (September 1988), pp. 90-95. 
Korol, J. K., "Graphical Perception and the Representation of Financial Information," Georgia Journal of Accounting (Spring 1986), pp. 147-157.

Kosslyn, S. M., "Understanding Charts and Graphs," Applied Cognitive Psychology (1989) 3, pp. 185-226.

Kosslyn, S. M., Elements of Graph Design (New York: W. H. Freeman,1994).

Lee, T. A., "The Changing Form of the Corporate Annual Report," Accounting Historians Journal (June 1994), pp. 215-232.

Leivian, G. M., "How to Communicate Financial Data More Effectively," Management Accounting (USA) (July 1980), pp. 31-34.

Mason, A. K., The Development of International Financial Reporting Standards, ICRA Paper No. 17 (Lancaster: ICRA, 1978).

McKinstry, S., "Designing the Annual Reports of Burton plc from 1930 to 1994," Accounting, Organizations and Society (1996) 21(1), pp. 89-111.

Meek, G. K., C. B. Roberts and S. J. Gray, "Factors Influencing Voluntary Annual Report Disclosures by U.S., U.K. and Continental European Multinational Corporations," Journal of International Business Studies (Third Quarter 1995), pp. 555-572.

Nobes, C. W., "Financial Reporting in North America," in Comparative International Accounting, 4th ed., C. W. Nobes and R. Parker (Cambridge: Prentice Hall, 1995).

Nobes, C. W. and R. H. Parker, Comparative International Accounting, 4th ed. (Cambridge: Prentice Hall, 1995).

Pany, K. and S. Wheeler, "Materiality: An Inter-Industry Comparison of the Magnitude and Stabilities of Various Quantitative Measures," Accounting Horizons (December 1989), pp. 71-78.

Porter, M., The Competitive Advantage of Nations (Macmillan, 1990).

Preston, A. M., C. Wright and J. J. Young, "Imag[in]ing Annual Reports," Accounting, Organizations and Society (1996) 21(1), pp. 113-137.

Revsine, L., "The Selective Financial Misrepresentation Hypothesis," Accounting Horizons (December 1991), pp. 16-27.

Roberts, C. B., International Trends in Social and Employee Reporting, Occasional Research Paper No. 6, Chartered Association of Certified Accountants (London: Certified Accountants Educational Trust, 1990).

Schmid, C. F. and S. E. Schmid, Handbook of Graphic Presentation, 2nd ed. (Ronald Press, 1979).

Schmid, C. F., Statistical Graphics: Design Principles and Practices (New York: John Wiley/Interscience, 1983).

Simcox, W. A., "A Method for Pragmatic Communication in Graphic Displays," Human Factors (August 1984) 26, pp. 483-487.

Squiers, C., "The Corporate Year in Pictures," in Contest of Meaning, Bolton, R. ed. (Massachusetts Institute of Technology 1989), pp. 207-218.

Steinbart, P. J., "The Auditor's Responsibility for the Accuracy of Graphs in Annual Reports: Some Evidence of the Need for Additional Guidance," Accounting Horizons (September 1989), pp. 60-70.

Sugden, A., "Public Relations: The Conflict with 'True and Fair'," Accountancy (September 1989), pp. 100-102.

Sullivan, J. J., "Financial Presentation Format and Managerial Decision Making: Tables Versus Graphs," Management Communication Quarterly (1988) 2(2), pp. 194-216.

The Accountants' Magazine, "Annual Reports 'Not True and Fair', Say Shareholders," (September 1992).

Thomas, A. P., "Towards a Contingency Theory of Corporate Financial Reporting Systems," Accounting, Auditing and Accountability Journal (1991) 4(4), pp. 40-57.

Times Books, The Times 1000 1990/91: Leading Companies in Britain and Overseas (London: Times Books, 1990). 
Tufte, E. R., The Visual Display of Quantitative Information (Cheshire, CT: Graphic Press, 1983).

Tversky, A. and D. Kahneman, "The Framing of Decisions and the Rationality of Choice," Science (1981) 211, pp. 453-458.

Tweedie, D. and G. Whittington, "Financial Reporting: Current Problems and Their Implications for Systematic Reform," Accounting and Business Research (Winter 1990), pp. 87-102.

Watts, R. and J. L. Zimmerman, Positive Accounting Theory (Englewood Cliffs, NJ: Prentice-Hall, 1986).

Weetman, P. and S. J. Gray, "International Financial Analysis and Comparative Performance: The Impact of UK Versus US Accounting Principles on Earnings," Journal of International Financial Management and Accounting (1990) 2(3), pp. 111-130. 